\title{
De l'élaboration au tour au tournage sur motte : difficultés motrices et conceptuelles
}

Agnès Gelbert

\section{(2) OpenEdition}

\section{Journals}

Édition électronique

URL : https://journals.openedition.org/tc/421

DOI : $10.4000 /$ tc. 421

ISSN : 1952-420X

Éditeur

Éditions de l'EHESS

\section{Édition imprimée}

Date de publication : 1 octobre 1998

ISSN : 0248-6016

\section{Référence électronique}

Agnès Gelbert, «De l'élaboration au tour au tournage sur motte : difficultés motrices et conceptuelles », Techniques \& Culture [En ligne], 30 | 1998, mis en ligne le 28 octobre 2005, consulté le 29 septembre 2022. URL : http://journals.openedition.org/tc/421 ; DOI : https://doi.org/10.4000/tc. 421

Ce document a été généré automatiquement le 29 septembre 2022.

Tous droits réservés 
De l'élaboration au tour au tournage sur motte : difficultés motrices et conceptuelles

Agnès Gelbert 